\title{
CAPITALISM VS. SOCIALISM: ANTINOMY OF NATIONS OR ANTINOMY OF SYSTEMS?
}

\begin{abstract}
This paper is a reflection on the legitimacy of commonly accepted opposition of the notions of "capitalism" and "socialism". The leading thesis is that although they can be considered as antinomies, their real referents should not be treated analogously. Capitalism, as understood by its very name, emerged in the second half of the 19th century and evolved constantly from this moment, often changing its main features. Socialism, in contrast, was created as a notion opposing the capitalistic reality of the $19^{\text {th }}$ century. Yet it never really existed in this form. The actual economic system, referred to as "socialism", was in fact a hybrid of capitalism and neo-feudal bureaucracy.

Keywords: social order, economic system, property, centralisation, expansion tendencies.

JEL: P51, B10, N01.
\end{abstract}

\section{Introduction}

The notions of 'capitalism' and 'socialism' have been traditionally contrasted in socio-economic thought ever since the idea of socialism as a political system emerged in the second half of the nineteenth century. The movement which developed at the time, and which aspired to represent the interests of employees (initially, mainly industrial workers), has left an imprint on the conceptual apparatus of sociology, philosophy, politology, and - last but not least - economy. Interestingly, the term 'socialism' - sometimes used interchangeably, or side by side, with 'communism' - was readily adopted even by those researchers who disapproved of the ideological content of the concept.

From the Russian Revolution of 1917 through the interwar period until the years 1945-1990, the word 'socialism' used to serve the purpose of self- 
identification of the political system created in the USSR, to be later implemented in Eastern Europe and many Third World countries. However, the designation was mainly used by the political elites of the above-mentioned states in reference to the systems established in their countries, even though the connection between the realities of those countries and the ideals of the nineteenth-century socialism was tenuous. The social democrats also held an attachment to the term 'socialism', even though they associated it with very different ideas than those espoused in the so-called Eastern countries. Their aspirations to establish a new social system were gradually displaced by a pursuit to modify and improve institutions created by the nineteenthcentury market economy, which in time came to be called 'capitalism', not only by its opponents but also by its advocates. This is to leave aside the implications of using the same word to indicate a political system, an economic system, and a fairly diverse collection of ideologies which legitimised that system. Nevertheless, all this caused the capitalism/socialism dichotomy to seem perfectly natural, if not clichéd, to the majority of twenty-first century readers.

The purpose of the present article is to challenge this alleged axiom. The author intends to demonstrate that a situation which the abovementioned antinomy depicts has never, in fact, taken place. Nowadays, we have to do neither with socialism nor with capitalism, which could be regarded as its antithesis. Capitalism has evolved into a system which, while retaining some of its original institutions, has fundamentally changed its character. Socialism, meanwhile, has never genuinely existed as a system. The totalitarian Soviet regime, emulated by its satellite states, the authoritarian state capitalism of China, or the many varieties of social market economy found in Western European countries are not - in the author's opinion - socialism. However, this is not only about the aptness of terminology. The stereotypical juxtaposition of 'capitalism' and 'socialism' obscures the striking analogies between the two systems, and - to an even greater extent - the similarities between large business entities which represent these formally contradictory systems in the global economy. This similarity is evident when we assume (which is no longer rare in modern economics) a global, instead of a national, approach to analysing economic orders.

"Authoritarian socialism and capitalism share strong tendencies toward centralising (one in the hands of the state, the other in the hands of corporations). They also both keep their respective systems going through ruthless expansion - whether through production for production's sake, in the case of Soviet-era socialism, or consumption for consumption's sake, in the case of consumer capitalism." [Klein 2016, 191]. Although this journalistic com- 
ment merely skims the surface of the problem, fails to identify the reasons for the similarities, and does not use accurate terminology, it can serve as an inspiration for further analysis.

\section{Capitalism: Model and Reality}

In mainstream economics, the word 'capitalism' was seldom used. What K. Marx and his disciples labelled as such, was a default for the mainstream. In debates on the differences among political systems the term 'capitalism' tended to be used only by one side of the argument, usually as an invective. It was only when the theory of economic systems developed that the word gained the status of a scientific designation. It was also disseminated through publications concerning the political transformation of Eastern European countries. This was also when the concept of 'variety of capitalism' emerged, which emphasised the considerable diversity of the system that used to be regarded as homogenous [Albert 1991].

The following definition, coined by T. Kowalik, is a typical example of the modern understanding of capitalism. It is a system in which profit is the main motive of action, while market and competition are the primary coordinating mechanisms. Socially, capitalism is founded on the division of citizens into those who possess capital and those who sell their labour as employees on contracts for work or services [Kowalik 2005, 35]. Notwithstanding the differences resulting from the ideological stance of the authors, most of the literature on capitalism focuses on three attributes of the system: prevalence of private ownership, freedom of business, and the mechanism of competition as a driving force of economic success. These are the distinctive features of all the varieties of capitalism. On closer examination, however, one can realise than none of the above attributes has remained unchanged in the course of the evolution of the last century and a half.

Whereas at the end of the nineteenth century private ownership indeed prevailed, the 1930s witnessed a mushrooming of state-owned enterprises which did not by any means serve to satisfy the needs of the public. State companies first appeared in the extractive industry, the weapons industry, and the energy industry. Their establishment was triggered by the Great Depression, but even after the Second World War, when the cyclical business fluctuations became much milder, the extent of state ownership did not decline. What happened instead was that enterprises belonging to the two sectors began to behave in a similar manner. Much of modern research into state ownership in market economies indicates that business strategies 
rather depend on the size of an entity and the kind of corporate governance rules which it applies [Bałtowski, Kwiatkowski 2018]. Admittedly, privately owned firms still outnumber state firms, but the predominance of the former is not as overwhelming as it used to be. Another important aspect of the problem is the changes which have been taking place in the management of joint-stock companies since the beginning of the twentieth century until now. The role of formal owners (shareholders) has been largely marginalised, which is reflected in the phrase 'managerial capitalism'. In large companies of a significant size the ties between the shareholders and the firm have atrophied. Owning shares does no longer entitle one to have a say about the future of the company. A share is nothing but a transferable security, an object of speculative transactions. Moreover, shareholders are usually not particularly concerned about the efficiency with which their companies are managed unless it has a direct impact on the prices of shares.

If the size of a company and the type of corporate governance are the main factors behind the strategies of firms, state-owned enterprises can frequently be more in line with the expectations of markets than large corporations. Typical features of state companies: multiplicity of aims, decisionmaking constraints, or application of soft budgetary restrictions, can also be found in many private firms. Large transnational corporations operate in many countries simultaneously and their strategies involve subordinating political decision-makers, taking advantage of clandestine ties between formally independent entities, corruption (particularly outside the mother country), or even instigating and financing military operations. The relationship between a state and a private company, especially in the case of authoritarian regimes, can involve a considerable degree of subordination. Finally, the 2008 crisis and the subsequent 'rescuing' of private banks by the American government clearly demonstrate that soft budgetary restrictions are available also to private sector organisations - as long as they are 'too big to fail.'

Another distinguishing characteristic of capitalism - economic freedom - can give rise to similar doubts. The term can be interpreted in two ways. It can be understood as the entitlement of an entrepreneur, thus only meaning freedom to make business choices. But it can also be understood as a property of economic systems. In this case, the array of qualities is much wider. Under the most comprehensive approaches, the definition of economic freedom can even overlap with the definition of capitalism. The Index of Economic Freedom, widely embraced by supporters of neoliberal views, is a good example of this way of thinking [Kondratowicz 2013, 39-41]. 
According to this approach, the capitalist system has five basic characteristics. The first one is the limited role of public administration (government), manifesting itself in low public consumption, social transfers and state subsidies kept to a minimum, lack of state-owned enterprises and institutions, or their marginal role and, finally, modest tax rates and low employment-related burdens imposed on business owners, which is a feature of economic policies rather than an element of a system. Still another trait is a legal guarantee of property rights, which requires efficient and impartial tribunals, and absence of any impact of the military on the rule of law and politics. The group of attributes, treated in the above-mentioned Index as a collective feature, also includes: an unrestricted real estate market and an efficient public security system. Altogether, they create a tapestry of political factors, well-functioning administration, and unconstrained freedom to manage one's capital.

'Good money' is the third characteristic of capitalism. It embodies stabilisation of purchasing power, which under a paper-money system can be seen as an orientation of state economic policy rather than a feature of a political order. The fourth characteristic - freedom of foreign exchange - is of equal importance as free movement of people and capital. It implies, however, unrestricted movement across borders, nowadays evoking inevitable associations with the problems caused by mass migration. The list of the most important characteristics of capitalism is closed by the scope of legal provisions passed by state authorities. What is considered important here is regulation of the credit market, the labour market and administrative laws regarding business activity, such as awarding concessions, or registration of businesses. These regulations are generally regarded as a necessary evil. The last two traits can probably be identified with the approval for globalisation processes.

It should be noted, however, that - to slightly narrow down the term - economic freedom can be identified with the sovereignty of the consumer [Miszewski 2014, 115]. In its wider, fragmented sense, which the neoliberal model implies, the phrase 'economic freedom' makes an impression of an attractive label, one, however, which does not have much in common with the notion of freedom known from philosophy.

The third constitutive characteristic of capitalism is the mechanism of market competition. There are two major aspects to this. The first one is the way in which this mechanism operates. Already J. Schumpeter [1976] emphasised that the textbook version of price competition had been replaced by innovation based on product, technology, and organisation. He pointed out that competition acts also when it is merely an ever-present threat. This 
approach makes it possible to disregard the issue of market transparency, so strongly highlighted by the perfect market model. The participants in competitive processes take decisions on the basis of their concept of the state of affairs, and not on the basis of factual information.

Nevertheless, what seems more important to competition is the role it is given in the overall concept of capitalism. It is usually believed to be a driver of business efficiency [Balcerowicz 1995, 59]. Competition promotes efficiency on a micro scale (in individual companies). It is common knowledge, however, that micro-efficiency does not automatically translate into macro-efficiency. This is doubtful even on the scale of a national economy, let alone on a global scale. Also, most discussions of market competition overlook the question of its costs. Meanwhile, they should take into account the social costs of the asymmetry in the 'entrepreneur - employee' relationship, stemming from the lowering of wages to reduce production costs, the uncertainty of employment, and lack of a guarantee of regular payments. Another aspect of competition costs is associated with the situation of those firms which lose in the competitive game. Of course, this kind of loss is inherent in the risk of business activity, but on a macro scale each defeat means that material resources must be seized by the winning side. Were these resources fully liquid, this would not cause social harm. Unfortunately, as technology advances, resources are increasingly becoming non-transferable, which generates sunk costs. A reduction in the number of jobs resulting from bankruptcy/closure of a company, or even just a deterioration of its market position, inevitably entails a waste of a part of the human capital which a given economy has at its disposal. This phenomenon can hardly be regarded as favourable to macro-scale efficiency.

Having said that, the mechanism of market competition does improve macro-scale efficiency, but only when it ensures optimisation (or at least improvement) of resource allocation. Apart from the issue of their liquidity, it should be noted here that appropriate (i.e. macro-efficiency-boosting) allocation is possible in so far as the market rewards the competing entities only for their micro-efficiency, not for their market power. Thus, no such effect can be achieved in a market which is even partly monopolised.

The above remarks do not describe an actually existing capitalist economy, but merely the concept which the mainstream economic theory holds of capitalism as a system. Let us, therefore, describe the socialist system in the same way. When using the word 'socialism', both economists and politicians often have in mind nothing but a certain theoretical construct. L. Balcerowicz notes that social values promised by the idea of socialism (social justice, fair distribution of income and wealth, or eradication of poverty 
and exploitation of the workers) have little in common with the system of 'real socialism', in which the main theoretical ideas still adhered to include the dominance of state enterprises and central planning as a co-ordinating mechanism of business policies. The decentralised model of socialist economy [Brus 1988], where co-ordination at the enterprise level is left to market forces, and only investment processes remain under state control, would also be consistent with the theoretical model.

The model of capitalism presented in the first section of this paper did exist in reality in the nineteenth century, particularly in its second half, after the industrial revolution had led to the erosion of those sectors of the economy in which relics of feudalism had still persisted. Since that time, capitalism has undergone numerous transformations. Apart from the question of technological progress and the associated modifications of the methods of competitive struggle, which J. Schumpeter widely discussed, a key role was played by the growing tendency towards capital concentration. The relationship between the scale of financial resources at one's disposal and his chances of success had been recognised since the dawn of capitalism. That tendency gave rise to new organisational and legal forms of enterprises, i.e. companies - at first partnerships, but then more and more frequently companies with shared capital, especially joint-stock companies. Already in the first half of the previous century, rapid development of the stock market led to the dominance of this type of enterprises in the global economy. The appearance of accelerated forms of concentration such as fusions and mergers made it possible for companies to increase in size. In the second half of the twentieth century, it became common practice that, in their quest for growth, corporations extended beyond the borders of their mother countries.

The contemporary model of a joint-stock company continually expanding through issue of shares entails further dispersion of capital and marginalisation of the role of owners as the key actors of the economic game. This role is gradually being taken over by managers, which is facilitated by the corporate governance model, popular in Anglo-Saxon countries, where the distinction between the major shareholders and the board members is becoming blurred. Shareholders who are eager to become strategic investors are an increasingly rare phenomenon. As the scope of corporate activities broadens, management operations become more complex, as a result of which the owners (who formally are still in control of their companies) in practice must rely on their managers and the experts selected by the managers. This phase of the evolution of capitalism was astutely described by J.K. Galbraith at the turn of the 1960s and 1970s [Galbraith 1973]. 
The evolution of capitalist firms did not stop, however, at the stage of managerial capitalism. A typical Galbraithian manager usually insisted on extensive development and bureaucratisation of management in pursuit of additional profits which could be derived from the resultant complexity of the company. Fusions and mergers contributed to the disappearance of substantive links between the activity of companies and their owners. A new category developed: namely that of passive investors (into pension funds, investment funds, investment banks, etc.), treating the shares they acquired as a source of income, but uninterested in the activity of the company. In somewhat simplified terms, it can be said that managers had to administer firms efficiently enough to make certain that shareholders received steady dividends (attractive, but only slightly more profitable than revenues from deposits or bonds) and that stock prices did not fluctuate too wildly. The availability and abundance of shares made them (especially in Anglo-Saxon countries) a popular medium for investing household savings. Additionally, the rise in the number of small shareholders strengthened the position of the managerial class.

The beginning of the twenty-first century witnessed a new stage in the evolution of large companies. Globalisation, combined with the informatisation of financial markets, caused a dramatic acceleration of the rate at which transactions were concluded and, proportionately, shortened the waiting period between investment and return on capital. Purely speculative transactions became more attractive than economic activity in even the most profitable sectors of the real economy. That resulted in renewed interest of large investors in the activity of companies in the turnovers of which financial transactions achieved increasingly higher shares. In major enterprises, alliances between the largest shareholders and management members began to be formed. The new type of business strategy which arose from this kind of structure involves pursuing short-term profit maximisation, along with the resultant increases in share prices, which is attained by drastic reduction of employment. Needless to say, in the long term, such measures weaken the capability of enterprises to maintain previous production levels, both in quantitative and qualitative terms. Before this happens, however, the investors who initiate this 'restructuring' will have managed to sell off their shares at a profit, while the co-operating managers will have resigned (usually with a golden handshake) from their positions. There even exist investment funds which specialise in operations of this kind.

The financialisation of the global economy has resulted in a situation when the effects of the real economy are not very significant from the point of view of potential investors. If a large company derives most of its profits from 
financial activities, the efficiency of traditional production, and its quality in particular, cease to matter. The oligopolisation of final goods markets reinforces this trend even more. The above-discussed picture shows how far capitalism has moved from its nineteenth-century roots. Given that the idea of socialism came into being as an antithesis of capitalism, one could venture to say that capitalism does not exist anymore, whereas real socialism has never actually existed. This claim should, of course, be considered merely in reference to the concept of the antinomy whose limitations the author of this study is attempting to prove.

\section{Socialism: idea and its applications}

The classical concept of socialism as a political and economic system is a simple antithesis of the key features of capitalism. Private ownership of enterprises was replaced with state ownership (dubiously referred to as 'social' or 'public' ownership). The freedom to do business was substituted by centralised control of the assets of enterprises (nominally belonging to the entire society). Finally, the market mechanism of co-ordinating economic activities was to be supplanted by central planning.

The objectives which socialism supposedly pursued are laudable. They include: eradication of unemployment, expanding the range of individual freedoms, replacing economic oligarchy with democracy, equality of opportunities, economic security for all, reduction of income disparities, free media (independent of political and financial influences), and elimination of resource wastefulness, allegedly typical of capitalist systems [Putnam 1943]. Putting aside the validity of the criticism of capitalism which underpinned the socialist project, it must be stressed that a system which embodied all the above ideals has never been constructed. It is also doubtful whether the political measures taken to implement the socialist model were truly intended to do so.

The so-called 'real socialism', established in 1917 following the October Revolution in Russia, and after the Second World War imposed on Eastern European countries and several other less developed states, mainly in Asia, definitely differed from the theoretical model of socialism. The system combined centralised political power with state ownership of enterprises. Real socialism has been widely criticised in the literature, but it is often ignored that many of the institutions (particularly informal ones) which were part of that system had been inherited, in a fairly unchanged form, from feudalism. Underneath the modernist trappings, the hierarchy within 
the ruling party strictly corresponded with the relations typical of a royal court - a tradition which in Russia dated back further than the nineteenth century. The feudal heritage of Soviet Russia included serfdom of peasants, primacy of the monarch over the rule of law (Tsarist autocracy), lack of trust in interpersonal relationships (both hierarchical and equal), and the insignificance of meritorious competences for the position of an individual in social hierarchy.

The mentality and actions of the Soviet bureaucratic caste closely resembled those of the 'chinovniks' from the Tsarist times or the 'noblesse de la robe' from mediaeval France. That was easily predictable on the basis of Marx's theory, which had envisaged the emergence of a new socialist system only after capitalism exhausted its developmental potential. At the beginning of the twentieth century, the Tsarist Russia was a semifeudal country, where capitalist market economy had only begun to take root. Therefore, real socialism could hardly have much in common with the expectations of the theorists. After a failed attempt at autarchy, the involvement of the Soviet economy in intersystem competition increasingly forced the USSR to imitate the strategies of its competitors. And yet, that strategy of emulation could not ensure adequate outcomes. What made it impossible was the incompatibility of the modernising character of the solutions used in developed capitalist countries, such as the cult of competences, the rule of law, or the democratic tradition, with the feudal mindset. As a result, the USSR attained success only in several fields associated with industrialisation, the development of the armaments sector (and the related achievements in space exploration) and education (primarily in the area of technical sciences), which was indispensable for the advancement of industry. On the path to industrialisation, however, real socialism was condemned to a never-ending catch-up game with its rivals, and since the economy was subordinated to that race, it developed disharmoniously, in time becoming more and more a caricature of itself.

The attractiveness of the goals associated with socialism prompted a search for solutions other than 'real socialism', ones reconcilable with the principles of market economy. This led to modifications to the capitalist system, mainly in the spirit of social democracy, but also noticeable in orthodox liberal thought. The result was that several new versions of the capitalist market economy came into being, all emphasising the importance of equal opportunities (the model supported by the Labour Party in 194664 ) or the welfare state (the ordoliberal model of social market economy developed in Germany in 1948-66 or the Scandinavian model based on continuous intermediation of the state between the trade unions and big busi- 
ness) [Czech 2013, 76-92]. Only in the last of the above cases was market co-ordination mechanism supplemented by non-market ones. But in all these varieties of the system, even in the Scandinavian model, private ownership of enterprises has remained emphatically prevalent. In those countries where the state business sector is allowed to grow, corporate governance is consistently organised in such a way that state entities behave similarly to private ones [Bałtowski, Kwiatkowski 2018, 121]. It is fair to say that despite the introduced modifications, none of the above examples can be regarded as an implementation of the original idea of socialism. What is more, globalisation makes it increasingly difficult to conduct, on the scale of a single country, an independent economic policy, free from any external influences. What can be observed, therefore, is osmosis of solutions, but comprehensive changes of the political and economic system would only be possible on a global, or at least supranational, scale.

Simultaneously, typically capitalist economies are undergoing changes which, paradoxically, bring them closer to what is usually associated with real socialism. The managerial revolution has made the structures and behaviours of large companies similar to one another, irrespective of whether they are owned by private or public shareholders. There is a growing temptation to relegate real business activity to secondary status in order to expand into financial markets. Enterprises continue to strive towards maximising their financial effects, but the link between the efficiency of a system and its capability to fully satisfy the needs reported by customers has been severed. In fact, consumers are no longer sovereign in their choices. The oligopolisation of the financial goods market forces customers to buy 'what is available', i.e. products manufactured in such vast numbers that their producers can benefit from the effects of scale. Emphasis on the quality of products has been abandoned in favour of their obsolescence, so as to ensure replacement demand. The marketing pressure which the development of mass media has enabled prevents consumers from realising the extent of their dependence. Thus, although the mechanisms behind the pursuit of ever higher efficiency have not changed, it is only financial efficiency that matters. The system is still there, but the purposes it serves are now different. It can be said, therefore, that the particular form of capitalism which inspired the birth of the idea of socialism and the antinomy in question has ceased to exist. We do not have to do with an actual antinomy of systems, but merely with an antinomy of notions. Anyway, this antinomy could not have occurred in reality since, as I have attempted to prove, socialism understood as an embodiment of the nineteenth-century idea has never been implemented. The real antinomy, meanwhile, is the juxtaposition of democratic and authoritarian 
political systems. Both can rely on economic coordination systems which include non-market elements such as injunctions and restrictions imposed by central governments. In other words, one can compare and contrast liberal capitalism, which is based on the rule of law (but not necessarily on a democratic rule) and state capitalism, which comes under many labels, including the leading role of the Communist Party of China.

\section{Capitalism and socialism in the light of the 'economy of the future'}

In the literature devoted to the search for a new paradigm of economic thinking, which would be more congruent with modern realities, the concept of the 'economy of the future' plays an important part [Kołodko 2014, Galbraith 2016, Koźmiński 2016, Csaba 2016, Woźniak 2016, Miszewski 2018a]. In view of this idea, it is worth to take a closer look at the potential usefulness of the eponymous antinomy as regards economic objectives, institutional framework of attaining these objectives, and the noticeable temporal coincidences of these frameworks.

Reflection on economic objectives can draw on the antinomy in question as the idea of socialism conveys the conviction that satisfying the needs of individuals (all needs, not only the material ones) and social well-being are at the core of these objectives. However, this argument does little more than indicate that distribution relations are more significant than production relations. The main weakness of both political projects is the assumption that economic processes occur on the scale of national economies. The adoption of a global perspective makes it possible to notice that the above-mentioned objectives can only be achieved if civilisation survives, and provided that economic inequalities are mitigated, which anyway is a sine qua non of this survival. Neither a system based on private ownership of enterprises (in practice on the dominance of transnational corporations) nor its socialist alternative offer solutions which would help attain these goals. In an optimistic scenario, there should be a change in the global economic order. However, there is no reason to believe that the new system will fall within the 'capitalism - socialism' continuum.

Considering the institutional framework of economic objectives, one should regard 'appropriation', which lies at the core of the institutional matrix, as the most important informal institution [Miszewski 2018]. At first glance, this institution evokes associations with the capitalist system, but neither the allegedly 'socialist' modifications of capitalism nor 'real social- 
ism' differ in this respect from classical capitalism. Both of them treat resources as inexhaustible, question the advisability of analysing the longterm consequences of large-scale economic projects, while the entities which make decision about the way the system operates are highly centralised (in capitalism - large corporations and the governments which they have subordinated; in Chinese-type capitalism - governments and the corporations which are dependent on them). Moreover, the 'capitalism - socialism' antinomy seems irrelevant in the context of the key issues of ecological balance and the necessity to put an end to global warming.

G.W. Kołodko points to the coincidence of development factors as a basis for explaining its constituent processes [Kołodko 2009, 329], saying that things are happening in the way they are happening because many things are happening concurrently [Kołodko 2014,36]. D. Acemoglu and J.A. Robinson [Acemoglu, Robinson 2012, 105-110] attach similar importance to coincidence of phenomena. The most significant, and not mentioned here yet, phenomena which could contribute to the advantage of one of the systems under consideration include:

- global debt and the associated quest for GDP growth, as well as rampant consumerism [Bałtowski, Miszewski 2014, 443],

- slipping of technology out of human control [Beck 2012, 82-83],

- global access to the Internet and mobile telephony ('transparency of the world').

In such a context, the differences between capitalism and socialism are easily discernible. At the turn of the $19^{\text {th }}$ and $20^{\text {th }}$ centuries, the development of science and technology became more cost intensive, which meant that only those branches of research which had its sponsors (state budgets, large corporations) could grow rapidly. Until the end of the 1980s, the arms race was a powerful driving force behind technical progress. However, for the last thirty years, the direction of research has been chiefly determined by the translatability of its outcomes to potential instant profits. As a result, progress is erratic: it occurs most rapidly in information technology (particularly IT services for financial market transactions), genetics, the pharmaceutical industry, and search for new sources of energy. Because technological progress has become dependent on the possibility of immediate commercialisation, the logic of research is reversed. Implementation of technologies and launching new products happens before research into their possible ramifications and side effects has been completed [Beck 2012, 165]. This is a significant problem as the side effects and consequences of technological development are globally dispersed (they may be geographically remote from their original source) and, more importantly, distant in time. This is 
the underlying cause behind many of today's global threats. Nevertheless, it would be difficult to prove that under the conditions of an alternative system (e.g. the Chinese one, which is not pure socialism but resembles it the most), the mechanism of technical progress would function differently. Capitalism is 'guilty' of releasing human creativity. This force, which in its early days was conducive to the development of civilisation, has nowadays become uncontrollable. The differences between the various points along the 'capitalism - socialism' axis are manifested in the fact that in modern capitalist economies, commercial applications of technical progress prevail, while in the more statist and authoritarian systems, military applications are more dominant. This does not, however, have any bearing on the - so far - slim chances of bringing this snowballing process under control.

The differences between capitalism and socialism are even less noticeable in the context of the deepening debt of countries, enterprises and households. In the case of countries, the key role is played by the temptation to accept permanent budget deficit, aroused by the advent of fiat money. The abandonment of the gold standard was not part of any economic policy but a by-product of the natural evolution of the capitalist economy. The fact that the first oil crisis became the immediate cause of that decision was, essentially, pure coincidence. Objectively speaking, gold reserves failed to keep pace with the value of trade, so what happened was inevitable anyway. The size of household debt partly stems from the altered nature of money, but primarily from the wave of consumerism triggered by 'great sellers'. GDP growth-seeking governments actually promote consumerist attitudes, although they do not usually do so openly. Since the sales of treasury bonds, which are the main source of financing public debt, depend on the level and growth of GDP, a state that fights consumerism would (in the short term) act against its own interest. All these paradoxical entanglements can affect every modern economy, regardless of whether it is predominated by state or private ownership. Given that public sectors are usually less efficient, it can be assumed that under socialism, vulnerability to problems caused by increased issuing of currency can be even more acute.

The third group of phenomena explained by means of coincidence include the 'transparency of the world' manifested in universal access to information, though not necessarily to the knowledge of how people live in remote, less well-off countries. This is a result of the appearance of numerous inventions from the fields of media and information technology, the dissemination of English as the world's second language, the globalisation of the market of services, and mass economic migrations. The information revolution is, of course, an aspect of technological progress but because of its 
cultural consequences it should be considered as a separate phenomenon. Contrary to popular belief, the civilisational benefits of the educational opportunities provided by the Internet are not as substantial as the profits drawn by huge IT-sector corporations (Google, Facebook, Amazon, and several others). Whereas, on the other hand, thanks to remote working systems, the world wide web enables global employers to exploit higher-skilled workers in less developed countries.

Also, global-scale media outlets inflame the hostility of the inhabitants of poorer countries towards the members of the richer nations, laying bare though not necessarily helping to understand - the cultural differences (particularly those related to moral and social conventions) between the wealthy North and the poor South. The image campaign, which is partly deliberate (stimulation of consumerism) and partly stems from an uncontrollable trend, has a dual effect. First, it strongly fosters migration. People from less well-off economies do not realise what life in better developed countries really looks like or what problems with adaptation they can expect when they move there. Neither are they aware of the competence gap which practically makes it impossible for them to attain in the new country a status equal to that which they had in their country of origin. Information from the Internet provides them merely with a selection of handpicked images which distort their world-view (often misguided anyway due to inadequate education). Moreover, collective envy is conducive to the development of terrorism. This is true not only about migrants themselves, but also their children and grandchildren born in the new homelands. It is in these later generations that people are struck with the fact that the status disparities and adaptation difficulties which at first seemed possible to overcome are, in fact, insurmountable.

In this single respect, there is a noticeable difference between capitalism and 'socialism' in the contemporary Chinese version. Capitalist societies are attached to civil liberties and resist attempts to restrict access to the Internet. The socialist system, centralised and fundamentally distinct from classical democracy, can more easily control the flow of content which may destabilise social order. This ethically dubious advantage finds practical implementation only in a few individual countries (China, Cuba) and has no impact on the state of the global system. Anyway, it is not certain whether even in such states total isolation from external influences is possible. Therefore, the significance of this inter-system difference is not major.

To sum up this discussion of the usefulness of the eponymous antinomy in the global perspective, it is worth referring to U. Beck. His concept of 'global risk society' conveys a critique of the neo-liberal capitalist market 
economy, making a clear distinction between the model of a national state as it has been understood so far and a 'cosmopolitan state' which benefits from co-operation with the global economic environment. Beck argues that countries which place the objectives of the international community above the interests of their national economies, in the long term achieve success and strengthen their positions [Beck 2012, 88]. Classically understood socialism always assumes building a national state, isolated from other countries because of its autarchic economic policy. In an attempt to find a match to this model among the actually existing 'non-capitalist' economies, one can wonder whether China (with its activity in the underdeveloped countries of Eastern Africa and several others) has not hijacked the idea of a 'cosmopolitan state' in order to enrich its national strategy. At present, however, there are no hard data available to confirm this intuition.

\section{Conclusion}

The differences between modern capitalism and what can be - more or less validly - regarded as socialism in practice prove to be negligible. It can be maintained that the capitalism which was an antithesis of socialism no longer exists, whereas socialism as a system constructed around a theoretical framework has never really become a reality. Instead, the label of 'socialism' has been attached to several neo-feudal economies (the Soviet Union, Eastern European countries before 1989, North Korea) or to a variety of capitalist market economies modified in terms of social policies and human rights. Therefore, the antinomy mentioned in the title of this article refers to theoretical notions but not to real economic systems.

\section{R E F E R E N C E S}

Acemoglu D., Robinson J.A., "Why Nations Fail. The Origins of Power, Prosperity, and Poverty", Crown Publishers, New York 2012.

Albert M., "Capitalisme contre Capitalisme", Seuil, Paris 1991.

Balcerowicz L., "Wolność i rozwój", Znak, Kraków 1995.

Bałtowski M., Kwiatkowski G., "Przedsiębiorstwa państwowe we współczesnej gospodarce", Wydawnictwo Naukowe PWN SA, Warszawa 2018.

Bałtowski M., Miszewski M., "Przeobrażenia cywilizacyjne a zmiany modelu polityki gospodarczej", Ekonomista No. 3/2014.

Beck U., "Społeczeństwo światowego ryzyka", Scholar, Warszawa 2012. 
Brus W., "Refleksje nad postępującą nieoznaczonością socjalizmu", in: "Demokracja i socjalizm", A. Jasińska (ed.), Oficyna Wydawnicza AFM Krakowskie Towarzystwo Edukacyjne sp. z o.o., Wrocław - Warszawa - Kraków 1992.

Csaba L., "Nieortodoksja, heterodoksja a ekonomia globalna", in: "Ekonomia przyszłości", M. Bałtowski (red.), Wydawnictwo Naukowe PWN SA, Warszawa 2016.

Czech S., "Gospodarka w służbie idei. Rzecz o modelu szwedzkim", Wydawnictwo Uniwersytetu Ekonomicznego w Katowicach, Katowice 2013.

Galbraith James K., Ekonomia wstecznego nurtu i nowy pragmatyzm: kryzysy i ewolucja ekonomii", in: "Ekonomia przyszłości", M. Bałtowski (ed.), Wydawnictwo Naukowe PWN SA, Warszawa 2016.

Galbraith John K., "Społeczeństwo dobrobytu - państwo przemysłowe", Państwowy Instytut Wydawniczy, Warszawa 1973.

Klein N., "To zmienia wszystko. Kapitalizm kontra klimat", Warszawskie Wydawnictwo Literackie Muza SA, Warszawa 2016.

Kołodko G.W., "Wędrujący świat", Prószyński i S-ka, Warszawa 2009.

Kołodko G.W., "Nowy pragmatyzm, czyli ekonomia i polityka dla przyszłości", in: "Ekonomia dla przyszłości. Fundamentalne problemy teorii ekonomii i polityki gospodarczej", E. Mączyńska (ed.), Polskie towarzystwo Ekonomiczne, Warszawa 2014.

Kondratowicz A., "Wolność gospodarcza. Pomiar, percepcja. Zmiany instytucjonalne", Towarzystwo Ekonomistów Polskich, Warszawa 2013.

Kowalik T., "Systemy gospodarcze", Fundacja Innowacja, Warszawa 2005.

Miszewski M., "Fundamenty współczesnej gospodarki rynkowej a rzeczywistość refleksja krytyczna", in: "25 lat gospodarki rynkowej w Polsce", B. Borkowska (ed.), Wydawnictwo Uniwersytetu Ekonomicznego we Wrocławiu, Wrocław 2014.

Miszewski M., "Ekonomia przyszłości jako podstawa zmiany kanonu polityki gospodarczej", in: "Ekonomia przyszłości. Państwo efektywne czy sprawiedliwe?", S. Lis, K. Zieliński (eds.), Wydawnictwo Uniwersytetu Ekonomicznego w Krakowie, Kraków 2018 [2018a].

Miszewski M., "Ekonomia przyszłości - jej potrzeba i zarys założeń", in: "Społeczna Gospodarka Rynkowa i integracja europejska", E. Mączyńska, P. Pysz (eds.), Fundacja Konrada Adenauera / Polskie Towarzystwo Ekonomiczne, Warszawa 2018 [2018b].

Putnam J., "Modern case for socialism", Boston 1943.

Schumpeter J., Capitalism, Socialism and Democracy, George Allen \& Unwin (Publishers) Ltd, Routledge London and New York 1976.

Woźniak M.G., "W kierunku ekonomii zintegrowanego rozwoju. Nadzieje i obawy", in: "Ekonomia przyszłości", M. Bałtowski (ed.), Wydawnictwo naukowe PWN, Warszawa 2016. 